\title{
Histopatologi Pankreas Tikus Putih (Rattus norvegicus L.) yang Diberi Pakan Tinggi Lemak dan Paparan Ekstrak Etanol Daun Mimba (Azadirachta indica A. Juss)
}

\section{Histopathology of Pancreas in White Rats (Rattus norvegicus L.) that Given with High-Fat Diet and Neem Leaf Ethanol Extract (Azadirachta indica A. Juss)}

\author{
Eka Wahyu Cahya Ningrum*, Sri Isdadiyanto, Siti Muflichatun Mardiati \\ Program Studi Biologi Fakultas Sains dan Matematika Universitas Diponegoro \\ *Email: ekawahyucahyaningrum@gmail.com
}

Diterima 12 Juni 2020 / Disetujui 12 September 2020

\begin{abstract}
ABSTRAK
Daun Mimba (Azadirachta indica A. Juss) mengandung antioksidan yang berpotensi untuk memperbaiki kerusakan pankreas. Penelitian ini bertujuan untuk menguji pengaruh ekstrak etanol daun mimba terhadap histopatologi pankreas tikus putih (Rattus norvegicus L.) yang diberi pakan tinggi lemak. Penelitian menggunakan Rancangan Acak Lengkap yang terdiri dari 6 perlakuan dan 4 kali pengulangan. Perlakuan meliputi kontrol (P0), pakan tinggi lemak (P1), simvastatin $8 \mathrm{mg}(\mathrm{P} 2)$, dan uji dosis ekstrak etanol daun mimba 75; 100; dan 125 mg (P3; P4; dan P5). Parameter yang diukur adalah diameter dan luas pulau langerhans. Hasil penelitian menunjukkan bahwa ekstrak etanol daun mimba tidak berpengaruh nyata $(p>0,05)$ terhadap diameter dan luas pulau langerhans serta tidak berpengaruh nyata $(p>0,05)$ terhadap skoring kerusakan pulau langerhans tikus putih. Kesimpulan dari penelitian ini adalah esktrak etanol daun mimba dengan dosis 75; 100; dan $125 \mathrm{mg}$ tidak dapat meningkatkan diameter dan luas pulau langerhans tikus putih yang diberi pakan tinggi lemak.
\end{abstract}

Kata kunci : ekstrak etanol daun Mimba, pakan tinggi lemak, pulau langerhans, tikus putih

\begin{abstract}
Neem leaf (Azadirachta indica A. Juss) contains antioxidants that have the potential to repair pancreatic damage. This study aimed to examine the effect of neem leaf ethanol extract on the histopathology of the pancreas of white rats (Rattus norvegicus L.) which were fed high-fat feed. The study used a completely randomized design consisting of 6 treatments and 4 repetitions. The treatments included control (P0), high-fat feed (P1), simvastatin $8 \mathrm{mg}$ (P2), and a test dose of ethanol extract of neem leaf 75; 100; and $125 \mathrm{mg}$ (P3; P4; and P5). The parameters measured was the diameter and area of the Langerhans islets. The results showed that the ethanol extract of neem leaf had no significant effect $(p>0,05)$ on the diameter and area of the Langerhans islets and no significant effect $(p>0,05)$ on the scoring damage of the white rats Langerhans islets. The conclusion of this study was the ethanol extract of neem leaf at a dose of 75; 100; and $125 \mathrm{mg}$ could not increase the diameter and area of the Langerhans islets of white rats that were fed high-fat feed.
\end{abstract}

Keywords : ethanol extact of Mimba leaf, high-fat feed, Langerhans islets, white rat

\section{PENDAHULUAN}

Perkembangan zaman telah mempengaruhi gaya hidup dan pola makan masyarakat secara bertahap. Masyarakat saat ini cenderung memiliki kebiasaan mengkonsumsi makanan tinggi lemak yang dapat mengarah ke peningkatan prevalensi penyakit degeneratif, salah satunya adalah diabetes melitus (Foley et al., 2019). DM tipe 2 menyumbang $90 \%$ dari semua kasus diabetes dan ditandai oleh resistensi insulin dan kerusakan selsel pankreas yang menyekresikan insulin. Hiperlipidemia memainkan peran penting dalam pathogenesis disfungsi sel $\beta$ diantara banyak faktor yang berkontribusi (Hao et al., 2007). Hiperlipidemia ditandai dengan peningkatan serum kolesterol total, low density lipoprotein (LDL), very low density lipoprotein (VLDL) dan penurunan kadar high density lipoprotein (HDL). Penelitian sebelumnya telah menunjukkan bahwa konsumsi 
makanan tinggi lemak yang tidak terkontrol juga menyebabkan resistensi insulin (IR) karena adanya asam lemak jenuh yang dapat mengganggu kerja insulin (Munshi et al., 2014).

Resistensi insulin juga dapat disebabkan oleh stress oksidatif. Diduga bahwa stres oksidatif berdampak pada kerusakan sel-sel asinar sehingga memicu otodigesti terhadap pankreas (Verlaan et al., 2006) yang berlanjut pada nekrosis sel $\beta$ pankreas (Tjahjono et al., 2013). Lemak trans dipercaya sebagai salah satu sumber dari stres oksidatif (Martin et al., 2007). Lemak trans dapat diperoleh dari minyak yang digunakan untuk menggoreng secara berulang-ulang. Penggorengan berulang dapat merubah asam lemak tidak jenuh menjadi asam lemak trans, gugus peroksida, dan senyawa radikal bebas. Asam lemak trans dapat meningkatkan kadar kolesterol LDL, tetapi secara bersamaan juga menurunkan kadar kolesterol HDL (Tuminah, 2009). Sartika et al. (2016) melalui penelitiannya mengungkapkan bahwa terjadi penurunan jumlah sel $\beta$ normal pada pankreas tikus wistar yang diberi pakan mengandung asam lemak trans. Penelitian tersebut didukung oleh Dusaulcy et al. (2019) yang menyatakan bahwa pemberian pakan tinggi lemak pada tikus putih dapat mempengaruhi ekspresi gen sel $\beta$ pankreas yang dapat menyebabkan disfungsi dan apoptosis sel $\beta$ pankreas.

Mimba (Azadirachta indica A. Juss) memiliki nilai pengobatan yang sangat baik. Banyak senyawa aktif biologis yang tekandung dalam ekstrak tanaman ini, termasuk alkaloid, senyawa fenolik seperti flavonoid, triterpenoid, karotenoid, steroid, dan keton (Debashri \& Mondal, 2012). Melalui penelitiannya, Bach et al. (2018) menemukan bahwa ekstrak etanol daun mimba memiliki aktivitas antidiabetes dengan menurunkan glukosa darah dan memperbaiki pulau langerhans dan sel $\beta$. Ekstrak etanol A. indica pada tikus diabetes dapat mencegah peningkatan kadar kolesterol, trigliserida (TG), low density lipoprotein (LDL), dan very low density lipoprotein (VLDL) dibanding tikus diabetes yang tidak diberikan ekstrak daun mimba, sedangkan kadar kolesterol high density lipoprotein (HDL) meningkat secara signifikan (Bisht \& Sisodia, 2010). Berdasarkan uraian di atas, maka perlu dilakukan penelitian untuk mendapatkan bukti dan informasi mengenai histopatologi pankreas tikus putih (Rattus norvegicus L.) yang diberi pakan tinggi lemak dan paparan ekstrak etanol daun mimba (Azadirachta indica A. Juss).

\section{METODE PENELITIAN}

\section{Hewan Uji}

Penelitian ini menggunakan 24 ekor tikus putih (Rattus norvegicus L.) jantan strain Wistar berumur 2 bulan dengan bobot berkisar 100-170 g. Tikus putih diaklimatisasi pada kondisi laboratorium selama 1 minggu dengan menempatkan 1 tikus pada setiap kandang pemeliharaan. Pakan dan minum tikus diberikan secara ad libitum.

\section{Pembuatan Ekstrak Etanol Daun Mimba}

Daun mimba diperoleh dari area kampus Fakultas Sains dan Matematika, Universitas Diponegoro. Daun dikeringkan dalam oven dengan suhu $45-50{ }^{\circ} \mathrm{C}$ dan diekstraksi dengan metode maserasi menggunakan pelarut etanol $70 \%$ (Hasana dkk., 2019). Daun mimba yang telah dikeringkan diblender hingga menjadi serbuk. Serbuk daun mimba sebanyak 100 gram diekstraksi dengan perbandingan antara serbuk daun mimba dan pelarut adalah 1:3. Kemudian larutan tersebut dimaserasi selama 48 jam dalam ruang tertutup dengan dilakukan penggojogan menggunakan rotary shaker. Setelah 48 jam sampel disaring menggunakan kertas filter kemudian ditampung dalam erlenmeyer. Filtrat yang telah diperoleh selanjutnya dilakukan evaporasi menggunakan rotary evaporator pada suhu $40{ }^{\circ} \mathrm{C}$ sampai diperoleh ekstrak pekat berbentuk serbuk (Supriyanto dkk., 2017).

\section{Pembuatan Pakan Tinggi Lemak}

Pakan tinggi lemak pada penelitian ini terdiri atas pakan komersial yang dicampur dengan minyak jelantah dan kuning telur bebek. Campuran pakan komersial dan minyak jelantah dibuat dengan 
cara setiap $30 \mathrm{~g}$ pakan komersil ditambahkan dengan $3 \mathrm{ml}$ minyak jelantah. Minyak jelantah (reused cooking oil) diperoleh dari minyak goreng kemasan satu liter yang digunakan untuk menggoreng tahu seberat $450 \mathrm{~g}$ selama 10 menit pada suhu $150-165^{\circ} \mathrm{C}$ dengan teknik deep fat frying (Muhartono dkk., 2018). Proses penggorengan dilakukan sebanyak sembilan kali (Hanung dkk., 2019). Pakan tinggi lemak selanjutnya diberikan kepada tikus sebanyak $30 \mathrm{~g} / \mathrm{hari}$ dan kuning telur bebek diberikan sebanyak $2,5 \mathrm{ml}$.

\section{Perlakuan Hewan Uji}

Hewan uji ditimbang dan diuji kadar kolesterolnya sebelum diberikan perlakuan. Pemberian perlakuan hewan uji terdiri atas 6 kelompok perlakuan yaitu: kelompok kontrol (P0); diberi pakan tinggi lemak (P1); diberi pakan tinggi lemak $+8 \mathrm{mg} / 200 \mathrm{gBB}$ simvastatin (P2); dan diberi pakan tinggi lemak dan uji dosis ekstrak etanol daun mimba 75; 100; dan 125 mg/200 gBB ekstrak etanol daun mimba (P3; P4; dan P5). Ekstrak etanol daun mimba dilakukan setiap hari pada sore hari. Pakan tinggi lemak berupa campuran pakan komersil dan minyak jelantah diberikan setiap hari pada pagi hari, sedangkan kuning telur bebek diberikan dua hari sekali pada pagi hari. Perlakuan diberikan selama 42 hari. Bobot badan tikus putih ditimbang setiap 1 minggu sekali, sedangkan konsumsi pakan dan minum diukur setiap hari.

\section{Pembedahan dan Pembuatan Preparat}

Teknik anestesi yang digunakan adalah teknik anestesi dengan menggunakan kloroform. Tikus dimasukkan ke dalam wadah kemudian ditutup rapat. Kloroform dituang ke dalam kapas kemudian dimasukkan ke dalam wadah yang telah berisi tikus tersebut. Tikus ditunggu selama sekitar dua menit untuk memastikan tikus telah kehilangan kesadarannya. Tikus diposisikan pada papan bedah dengan menggunakan jarum dan dibedah mulai dari bagian abdomen bawah hingga ke tulang rusuknya menggunakan gunting bedah (Kusuma dkk., 2019). Pankreas diambil, lalu dicuci dengan menggunakan larutan fisiologis selama 30 menit. Organ kemudian difiksasi dengan larutan BNF 10\% selama minimal 24 jam (Nowacek \& Kiernan, 2010).

Pembuatan preparat pankreas diawali dengan pemotongan sampel jaringan pankreas dengan ukuran 3 x $3 \mathrm{~mm}$. Sampel jaringan kemudian dimasukkan ke dalam tissue cassete yang telah diberi label (Nesti \& Baidlowi, 2017). Tahap selanjutnya dilakukan dehidrasi jaringan menggunakan tissue processor yang dimaksudkan untuk mengeluarkan air dalam jaringan menggunakan alkohol dengan konsentrasi bertingkat. Sampel yang telah didehidrasi selanjutnya dilakukan proses clearing, yaitu pembersihan jaringan menggunakan reagen pembersih (clearing agent), yaitu xylol. Reagen pembersih tersebut selanjutnya dikeluarkan dari jaringan dan diganti dengan parafin cair dengan cara memasukkan larutan parafin cair sehingga parafin terpenetrasi ke dalam jaringan, proses ini disebut impregnasi. Parafin yang digunakan mempunyai titik cair $56-58^{\circ} \mathrm{C}$. Jaringan yang berada di dalam embedding cassette akan dipindahkan ke dalam base mold, kemudian diisi dengan parafin cair dan dilekatkan pada embedding cassette yang disebut blok. Jaringan dalam balok yang telah beku selanjutnya dipotong pada ketebalan irisan 4 mikron dengan rotary microtome. Irisan tersebut ditempel pada gelas objek yang sebelumnya diolesi mayer's egg albumin dan ditetesi aquades kemudian dikeringkan pada suhu kamar (Isdadiyanto, 2018).

\section{Pewarnaan Preparat}

Metode pewarnaan yang digunakan adalah Hematoxylin Ehrlich-Eosin. Sayatan yang telah dilekatkan pada kaca objek dideparafinisasi dengan xylol sebanyak dua kali selama lima menit. Proses selanjutnya adalah dihidrasi dengan alkohol bertingkat $95 \%$; $90 \%$; $80 \%$ masing-masing selama dua menit dan dibilas dengan aquades. Pewarnaan dengan Haematoxyllin Ehrlich dilakukan selama dua menit lalu dicuci dengan air mengalir sampai bersih, sedangkan pewarnaan dengan Eosin dilakukan selama lima menit. Tahap berikutnya adalah dehidrasi menggunakan alkohol bertingkat $80 \%$; $90 \%$; $95 \%$ masing-masing selama dua menit, selanjutnya clearing menggunakan xylol 
sebanyak dua kali (masing-masing selama dua menit) dan dikering anginkan. Tahap terakhir adalah proses mounting, yaitu dengan memberikan perekat entelan pada preparat dan menutupnya dengan cover glass (Isdadiyanto, 2018).

\section{Pengamatan Preparat}

Setiap preparat diamati sebanyak lima bidang pandang. Pemeriksaan histopatologi dilakukan melalui analisis morfometrik dengan mengukur diameter dan luas pulau langerhans (Farid dkk., 2014). Diameter pulau langerhans diperoleh dengan cara mengukur sumbu terbesar dan sumbu terkecil pada pulau langerhans. Sumbu terbesar dinyatakan sebagai (a) dan sumbu terkecil dinyatakan sebagai (b) (Morini et al., 2006). Masing-masing sumbu diameter pulau langerhans selanjutnya diukur dengan menggunakan mikroskop pada perbesaran $40 \times$ (Rajesh et al., 2017). Perubahan histologis pada pulau langerhans dan sel-sel yang ada didalamnya dicatat untuk dilakukan skoring dengan nilai skor 0-4 (Tandi dkk., 2017).

\section{Analisis Data}

Data pengamatan diameter dan luas pulau langerhans yang telah terdistribusi normal dan bervarian homogen dianalisis secara statistik parametrik menggunakan uji Analysis of Variance (ANOVA) satu arah (Hinton, 2013). Kerusakan yang terjadi pada pulau langerhans pankreas dilakukan skoring dan dianalisis secara statistik dengan analisis non parametrik menggunakan uji Kruskal-Wallis. Data struktur histologi pankreas selanjutnya disajikan secara deskriptif dengan berdasarkan skoring kerusakan pulau langerhans pankreas. Pengolahan data dilakukan dengan menggunakan program software SPSS 23.0 (Tandi dkk., 2017).

\section{HASIL DAN PEMBAHASAN}

Hasil analisis statistik rerata diameter dan luas pulau langerhans tikus putih (Rattus norvegicus L.) setelah pemberian pakan tinggi lemak dan paparan ekstrak etanol daun mimba (Azadirachta indica A. Juss) yang dikelompokkan menurut masing-masing perlakuan selama rentang waktu 42 hari menggunakan uji ANOVA dengan taraf kepercayaan 95\% disajikan pada Tabel 1. Hasil uji ANOVA rerata diameter pulau langerhans menunjukkan $\mathrm{p}=0,193$, yang artinya tidak ada perbedaan rerata diameter pulau langerhans pada kelompok perlakuan secara signifikan. Hasil menunjukkan bahwa pemberian ekstrak etanol daun mimba (Azadirachta indica A. Juss) dengan berbagai dosis $(75,100$, dan $125 \mathrm{mg} / 200 \mathrm{gBB})$ tidak berpengaruh nyata $(\mathrm{p}>0,05)$ pada diameter pulau langerhans tikus putih (Rattus norvegicus L.). Hal tersebut dikarenakan dosis ekstrak daun mimba yang digunakan masih dalam dosis aman. Hal ini sesuai dengan penelitian Suhendro et al. (2018) yang menyatakan bahwa pemberian ekstrak etanol daun mimba dosis 50 - $200 \mathrm{mg} / \mathrm{g}$ BB pada tikus wistar masih dalam dosis aman. Berdasarkan hasil penelitian, nilai rerata diameter pulau langerhans pada kelompok perlakuan P0, P1, P2, P3, P4; dan P5 secara berturut-turut adalah 116,$80 ; 128,05$; 124,$82 ; 117,44 ; 133,66$; dan $141,87 \mu \mathrm{m}$. Rerata diameter pulau langerhans tersebut tergolong normal yaitu berkisar antara $100 \mu \mathrm{m}$ (Mescher, 2016) hingga $150 \mu \mathrm{m}$ (Kahn, et al., 2005).

Tabel 1. juga menunjukkan hasil uji ANOVA rerata luas pulau langerhans menunjukkan $\mathrm{p}=$ 0,193 , yang artinya tidak ada perbedaan secara signifikan rerata luas pulau langerhans pada kelompok perlakuan. Hasil tidak beda nyata pada uji statistik menunjukkan bahwa pemberian ekstrak etanol daun mimba (Azadirachta indica A. Juss) dengan berbagai dosis $(75,100$, dan $125 \mathrm{mg} / 200$ gBB) tidak berpengaruh nyata $(\mathrm{p}>0,05)$ pada rerata luas pulau langerhans tikus putih (Rattus norvegicus L.). Berdasarkan hasil penelitian, nilai rerata luas pulau langerhans pada kelompok perlakuan P0, P1, P2, P3, P4; dan P5 secara berturut-turut adalah $10.805,34 ; 13.033,99$; $12.372,13 ; 10.868,43 ; 14.289,47$; dan $15.882,44$ $\mu \mathrm{m}$. Rerata luas pulau langerhans masing-masing kelompok perlakuan tersebut menunjukkan hasil mendekati kelompok kontrol. Hasil tersebut dikarenakan pemberian dosis ekstrak etanol daun mimba yang masih dapat ditolerir oleh tubuh. Studi berdasarkan model hewan menunjukan bahwa mimba merupakan tanaman obat yang aman dan 
mampu memodulasi banyak proses biologis tanpa efek samping (Alzohairy, 2016). Hal ini didukung dengan penelitian Akinola et al. (2010) yang menyatakan bahwa ekstrak etanol daun mimba merupakan herbal yang aman dikonsumsi dan mampu meningkatkan morfologi pulau langerhans pada tikus putih yang mengalami kerusakan akibat adanya stress oksidatif

Tabel 1. Data Rerata Diameter dan Luas Pulau Langerhans

\begin{tabular}{|c|c|c|}
\hline \multirow[b]{2}{*}{$\begin{array}{l}\text { Kelompok } \\
\text { Perlakuan }\end{array}$} & \multicolumn{2}{|c|}{$\begin{array}{ll}\text { Variabel } & \text { Vabs }\end{array}$} \\
\hline & $\begin{array}{c}\text { Diameter Pulau Langerhans } \\
(\mu \mathrm{m}) \\
(\text { Mean } \pm \text { SD })\end{array}$ & $\begin{array}{c}\text { Luas Pulau Langerhans } \\
\qquad \begin{array}{c}\left(\mu \mathbf{m}^{2}\right) \\
(\text { Mean } \pm \text { SD })\end{array}\end{array}$ \\
\hline P0 & $116,80 \pm 12,740$ & $10.805,34 \pm 2.461,207$ \\
\hline P1 & $128,05 \pm 16,599$ & $13.033,99 \pm 3.479,415$ \\
\hline $\mathrm{P} 2$ & $124,82 \pm 15,515$ & $12.372,13 \pm 3.056,694$ \\
\hline P3 & $117,44 \pm 8,467$ & $10.868,43 \pm 1.542,451$ \\
\hline P4 & $133,66 \pm 21,223$ & $14.289,47 \pm 4.409,723$ \\
\hline P5 & $141,87 \pm 11,876$ & $15.882,44 \pm 2.658,567$ \\
\hline
\end{tabular}

Keterangan: P0: Kontrol negatif, P1: Kontrol positif, diberi pakan tinggi lemak, P2: Kontrol positif, diberi pakan tinggi lemak $+8 \mathrm{mg} / 200 \mathrm{gBB}$ simvastatin, P3: Kontrol positif, diberi pakan tinggi lemak $+75 \mathrm{mg} / 200 \mathrm{gBB}$ ekstrak etanol daun $A$. indica, P4: Kontrol positif, diberi pakan tinggi lemak + $100 \mathrm{mg} / 200 \mathrm{gBB}$ ekstrak etanol daun A. indica, P5: Kontrol positif, diberi pakan tinggi lemak + $125 \mathrm{mg} / 200 \mathrm{gBB}$ ekstrak etanol daun A. indica

Pengamatan histopatologi pankreas tikus putih (Rattus norvegicus L.) dilakukan dengan pengamatan struktur mikroanatomi pulau Langerhans tikus putih pada setiap kelompok perlakuan. Selanjutnya dilakukan skoring kerusakan pulau Langerhans menggunakan skor 04 (skor 0: pulau langerhans normal, tidak ada perubahan pada batas pulau langerhans, jumlah sel, nekrotik sel dan bentuk sel; skor 1: batas jelas, jumlah sel mulai berkurang, nekrotik sel belum terlihat hanya terjadi degenerasi sel, bentuk sel normal; skor 2: batas mulai tidak jelas, jumlah sel berkurang, terjadi degenerasi sel dan bentuk sel ada yang tidak normal; skor 3: batas tidak jelas, jumlah sel berkurang, nekrotik sel terlihat dan bentuk sel banyak tidak normal; skor 4: batas sangat tidak jelas, jumlah sel banyak yang berkurang dan hampir keseluruhan sel nekrotik dan bentuk sel tidak normal). Berdasarkan data skoring kerusakan pankreas, pada tikus kontrol negatif (P0), kontrol positif yang diberi pakan tinggi lemak +75 $\mathrm{mg} / 200 \mathrm{gBB}$ ekstrak etanol daun A. indica (P3), kontrol positif yang diberi pakan tinggi lemak +100 $\mathrm{mg} / 200 \mathrm{gBB}$ ekstrak etanol daun A. indica (P4), dan kontrol positif yang diberi pakan tinggi lemak +125
mg/200gBB ekstrak etanol daun A. indica (P5) mendapatkan skoring 0 yang menunjukkan struktur histologis pankreas normal berupa batas pulau langerhans yang masih jelas, jumlah sel dan bentuk sel yang normal serta tidak terdapat nekrotik sel. Struktur tersebut sesuai dengan pernyataan bahwa endokrin pankreas kira-kira tersusun atas 1 juta pulau-pulau langerhans yang masing-masing terbungkus dalam selubung serat retikular tipis (Gartner \& Hiatt, 2007).

Selubung inilah yang memisahkan pulau langerhans dengan jaringan asinar. Pulau langerhans merupakan massa sel endokrin padat berbentuk bulat atau oval yang melekat pada jaringan eksokrin asinar. Sel-sel pada pulau langerhans berbentuk poligonal atau melingkar, lebih kecil, dan berwarna lebih terang dibanding sel-sel asinar yang ada disekitarnya (Mescher, 2016).

Perubahan histologis pankreas tikus putih terjadi pada tikus kontrol positif yang diberi pakan tinggi lemak (P1) yang mendapatkan skor 1,50 dan tikus yang diberi pakan tinggi lemak +8 $\mathrm{mg} / 200 \mathrm{gBB}$ simvastatin (P2) (Gambar 1.) yang mendapatkan skor 1,00 ditunjukkan dengan adanya 
perubahan berupa mulai berkurangnya jumlah sel dan terjadi degenerasi sel. Berkurangnya jumlah sel dan terjadinya degenerasi sel pada pankreas disebabkan pemberian pakan tinggi lemak dan adanya kandungan minyak trans yang terdapat dalam minyak jelantah dalam pakan tingi lemak. Hal ini sesuai dengan pernyataan bahwa pemberian pakan tinggi lemak dan adanya obesitas berdampak pada efek jangka panjang inkubasi pulau langerhans oleh asam lemak bebas terhadap sekresi insulin (Collins et al., 2010) yang berkorelasi dengan peningkatan jumlah lemak di dalam pulau langerhans (Hoppa et al., 2009) dan eksokrin pankreas yang ada di sekitarnya (Pinnick et al., 2008).

Pemberian pakan tinggi lemak pada tikus dapat mempengaruhi ekspresi gen sel $\beta$ pankreas yang dapat menyebabkan disfungsi dan apoptosis sel $\beta$ pankreas (Dusaulcy et al., 2019). Hal ini sejalan dengan penelitian Sartika et al. (2016) bahwa terdapat penurunan jumlah sel $\beta$ normal pada pankreas tikus wistar yang diberi pakan yang mengandung asam lemak trans. Hal ini didukung dengan pendapat yang menyatakan bahwa lemak trans dipercaya sebagai salah satu sumber dari stres oksidatif Martin et al. (2007) yaitu suatu kondisi dimana terjadi kelebihan reactive oxygen species (ROS) yang merupakan radikal bebas akibat tidak seimbangnya laju produksi dengan laju pembuangan ROS karena berlebihnya produksi ROS (McMichael, 2007). Stres oksidatif sangat berkorelasi dengan berbagai penyakit metabolik dan kondisi inflamasi (Noeman et al., 2011) seperti pankreatitis akut (Andican et al., 2005) maupun kronis. Stres oksidatif diduga berdampak pada kerusakan sel-sel asinar sehingga memicu otodigesti terhadap pankreas (Verlaan et al., 2006) yang berlanjut pada degenerasi dan nekrosis sel $\beta$ pankreas (Tjahjono et al., 2013).
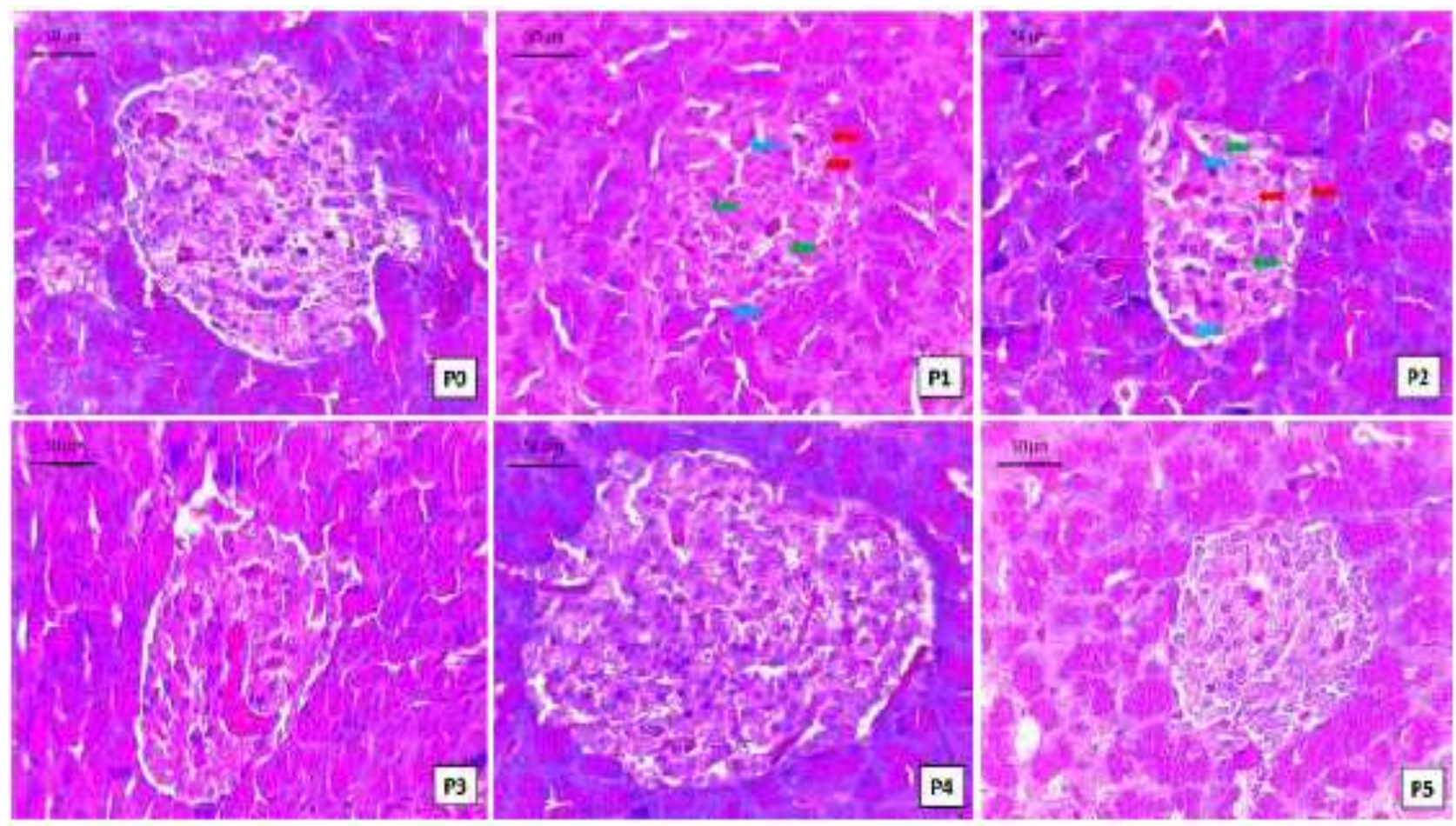

Gambar 1. Struktur Histologi Pankreas Tikus Putih (pewarnaan Hematoksilin \& Eosin, perbesaran 400X)

Berdasarkan hasil pengamatan, struktur histologis pankreas tikus putih pada kelompok perlakuan kontrol positif yang diberi pakan tinggi lemak $+100 \mathrm{mg} / 200 \mathrm{gBB}$ ekstrak etanol daun $A$. indica (P4) lebih mendekati kelompok kontrol negatif (P0) dibandingkan dengan kontrol positif yang diberi pakan tinggi lemak $+75 \mathrm{mg} / 200 \mathrm{gBB}$ ekstrak etanol daun A. indica (P3) dan kontrol 
positif yang diberi pakan tinggi lemak +125 $\mathrm{mg} / 200 \mathrm{gBB}$ ekstrak etanol daun A. indica (P5) (Gambar 1).

Struktur histologis pankreas tikus putih pada kelompok perlakuan kontrol positif yang diberi pakan tinggi lemak $+100 \mathrm{mg} / 200 \mathrm{gBB}$ ekstrak etanol daun $A$. indica (P4) yang menunjukkan struktur normal mendekati kelompok kontrol dikarenakan pemberian ekstrak daun mimba yang mengandung antioksidan. Hal ini sesuai dengan pendapat Supriyanto dkk. (2017) yang menyatakan bahwa ekstrak etanol daun mimba mengandung flavonoid, tannin, terpenoid, dan saponin serta memiliki aktivitas antioksidan yang kuat. Penelitian Akpan et al. (2012) juga menyatakan bahwa pemberian ekstrak daun $A$. indica dapat meningkatkan regenerasi sel-sel pada pulau langerhans pada tikus. Penambahan senyawa flavonoid pada sel juga dapat mengurangi jumlah ROS sehingga dapat membantu mengembalikan integritas sel dan menambah viabilitas suatu sel. Semakin baik struktur histologis pankreas diduga karena senyawa flavonoid yang terkandung bahan pangan mampu mengikat dan mengurangi jumlah ROS, penyebab nekrosis pada sel beta pankreas. Mekanisme flavonoid melawan radikal bebas, yakni dengan menekan pembentukan ROS, mengikat ROS, dan meningkatkan regulasi atau perlindungan pertahanan antioksidan. Flavonoid mengikat ROS dengan menyumbangkan atom hidrogren dan elektronnya untuk radikal hidroksil, peroksil, dan peroksinirit. Flavonoid menekan pembentukan ROS dengan menghambat aktivitas enzim superoksida dismutase yang terlibat dalam pembentukan ROS (Kumar \& Pandey, 2013).

\section{KESIMPULAN}

Ekstrak etanol daun mimba dengan dosis 75 ; 100; dan $125 \mathrm{mg}$ tidak dapat meningkatkan diameter dan luas pulau langerhans tikus putih yang diberi pakan tinggi lemak. Selain itu, tidak terjadi perubahan signifikan pada histopatologi pankreas tikus putih (Rattus norvegicus L.) yang diberi pakan tinggi lemak dan paparan ekstrak etanol daun mimba (Azadirachta indica A. Juss) dengan berbagai dosis $(75,100$, dan $125 \mathrm{mg} / 200 \mathrm{gBB})$. Berdasarkan hal tersebut maka dapat disimpulkan bahwa ekstrak etanol daun mimba (Azadirachta indica A. Juss) dengan berbagai dosis (75, 100, dan $125 \mathrm{mg} / 200 \mathrm{gBB}$ ) masih tergolong dalam kadar aman untuk dikonsumsi dan mampu ditoleransi oleh tubuh tikus putih serta kandungan antioksidan ekstrak etanol daun mimba mampu memperbaiki struktur sel-sel pulau langerhans dari kerusakan.

\section{DAFTAR PUSTAKA}

Akinola, O. B., Cxton-Martins, E. A., \& Dini, L. 2010. Chronic Treatment with Eyhanolic Extract of the Leaves of Azadirachta indica Ameliorates Lesions of Pancreatis Islets in Streptozotocin Diabetes. Int. J. Morphol. 28(1): 291-302.

Akpan, H D., Ekaidem, I. S., Usoh, I F., Ebong, P. E., \& Isong, N. B. 2012. Effect of Aquos Extract of Azadirachta indica (Neem) Leaves on Some Indices of Pancreatic Function in Alloxan-induced Diabetic Wistar Rats. Pharmacologia. 3(9): 420425 .

Alzohairy, M. A. 2016. Therapeutics Role of Azadirachta indica (Neem) and Their Active Constituents in Diseases Prevention and Treatment. Evidence-Based Complementary and Alternative Medicine. $1-11$.

Andican, G., Gelisgen, R., Unal, E., Tortum, O. B., Dervisoglu, S., Karahasasoglu, T, \& Burcak, G. 2005. Oxidative stress and nitric oxide in rats with alcohol-induced acute pancreatitis. World $J$ Gastroenterol. 1(11):2340-2345.

Bach, L. T., Dung, L. T., Tuan, N. T., Phuong, N. T., Kestemont, P., Quetin-Leclercq, J. \& Hue, B. T. B. 2018. Protective Effect of Pancreatic B Cells MIN6 by Some Medicinal Plants in the Mekong Delta. Vietnam J. Chem. 56(5): 637-641.

Bisht, S. \& Sisodia, S., S. 2010. AntiHyperglycemic and Antidyslipidemic Potential of Azadirachta indica Leaf Extract in STZ-Induced Diabetes Mellitus. Journal of Pharmaceutical Sciences and Research. 2(10): 622-627. 
Collins, S. C., Hoppa, M. B., Walker, J. N., Amisten, S., Abdulkhader, F., \& Bengtsson, M. (2010). Progression of dietinduced diabetes in C57B16J mice involves functional dissociation of $\mathrm{Ca}^{+}$channels from secretory vesicles. J. Diabetes 1(59): 1192-1201.

Debashri, M. \& Mondal, T. 2012. A Review on efficacy of Azadirachta indica A. Juss based biopesticides: An Indian perspective. Research Journal of Recent Sciences 1(3): 94-99.

Dusaulcy, R., Handgraaf, S., Visentin, F., Howald, C., Dermitzakis, E. T., Philippe, J. \& Gosmain, Y. 2019. High-fat diet impacts more changes in beta-cell compared to alpha-cell transcriptome. PLoS ONE 14(3): $1-16$.

Farid, M., Darwin, E., \& Sulastri, D. 2014. Pengaruh Hiperglikemia terhadap Gambaran Histopatologis Pulau langerhans Mencit. Jurnal Kesehatan Andalas. 3(3): 420-428.

Foley, E., Akhavan, N., George, K., Siebert, S., \& Munoz, J. 2019. Body Composition in Subjects with Prediabetes and Type 2 Diabetes. Current Developments in Nutrition. 3(1): 8-29.

Gartner, L. P., \& Hiatt, J. P. 2007. Concise Histology. $\quad 3^{\text {rd }}$ Edition. Elsevier, Philadelphia.

Hanung, A., Fanti S., \& Ainun R. 2019. Pengaruh Frekuensi Penggorengan Minyak Jelantah Terhadap Diameter dan Gambaran Histopatologi Lumen Aorta Tikus Wistar (Rattus novergicus). Jurnal Kedokteran Diponegoro 8(1): 26-37.

Hao, M., Head, W. S., Gunawardana, S. C., Hasty, A. H., \& Pitson, D. W. 2007. Direct Effect of Cholesterol on Insulin Secretion. Diabetes. 56(9): 2328-2338.

Hasana, A., Sitasiwi, A. \& Isdadiyanto, S. 2019. Hepatosomatik Indeks dan Diameter Hepatosit Mencit (Mus musculus L.) Betina Setelah Paparan Ekstrak Etanol Daun
Mimba (Azadirachta indica Juss.). Jurnal Pro-Life 6(1): 1-12.

Hinton, P. 2013. Statistics Explained. $3^{\text {rd }}$ Edition. Routledge, London.

Hoppa, M. B., Collins, S., Ramracheya, R., Hodson, L., Amisten, S., \& Zhang, Q. 2009. Chronic palmitate exposure inhibits insulin secretion by dissociation of $\mathrm{Ca}\left({ }^{2+}\right)$ channels from secretory granules. Cell Metab. 1(10): 455-465.

Isdadiyanto, S. 2018. Pengaruh Waktu Fermentasi Teh Kombucha Kadar 50 \% Terhadap Tebal Dinding dan Diameter Lumen Arteria Koronaria Tikus Putih. Bioma. 20 (2): $140-145$.

Kahn, C. R. K., Weir, G. C., King, G. L., Jacobson, A. M., Moses, A C., Smith, R. J. 2005. Joslin's Diabetes Mellitus. 14 ${ }^{\text {th }}$ Edition. Boston: Lipincott Williams \& Wilkins.

Kumar, S. \& Pandey, A. 2013. Chemistry and Biological Activities of Flavonoids: An Overview. The Scientific World Journal. 2013: 1-6.

Kusuma, A. B., Saraswati, T. R., \& Sitasiwi, A. J. 2019. Efek Pemberian Daun Mimba (Azadirachta indica) Terhadap Diameter Hepatosit Tikus (Rattus norvegicus). Bioma. 21(2): 106-113.

Martin, C. A., Milinsk, M. C., Visentainer, J. V., Matsushita, M., \& De-Souza, N. D. 2007. Trans fatty acidforming processes in foods: a review. An Acad Bras Cienc. 1(79): $343-$ 350 .

McMichael, M. A. 2007. Oxidative stress, antioxidants, and assessment of oxidative stress in dogs and cats. J Am Vet Med Assoc. 231(5):714-20.

Mescher, A. L. 2016. Junqueira's Basic Histology Text and Atlas. $14^{\text {th }}$ Edition. McGraw-Hill, USA.

Morini, S., Braun, M., Onori, P., Cicalese, L., Elias, G., Gaudio, E. \& Rastellini, C. 2006. Morphological changes of isolated rat pancreatic islets: a structural, ultrastructural 
and morphometric study. J. Anat. 209(2006): 381-392.

Muhartono, M., Agung, Y., Nindya T., Tri, N. \& Oktafany. 2018. Minyak Jelantah Menyebabkan Kerusakan pada Arteri Koronaria, Miokardium, dan Hepar Tikus Putih (Rattus norvegicus) Jantan Galur Sprague dawley. Jurnal Kedokteran Unila 2(2): 129-135.

Munshi, R. P., Joshi, S. G., \& Rane, B. N. 2014. Development of an experimental diet model in rats to study hyperlipidemia and insulin resistance and markers for coronary heart disease. Indian Journal of Pharmacology. 46(3): 271-276.

Nesti, D. R. \& Baidlowi, A. 2017. Profil Glukosa Darah, Lipid dan Visualisasi Pulau langerhans sebagai Imunoreaktor Insulin dan Glukagon pada Pankreas Tikus (Rattus norvegicus) Obesitas Menggunakan Teknik Imunohistokimia. Jurnal Nasional Teknologi Terapan. 1(1): $24-32$.

Noeman, S. A., Hamooda, H. E., \& Baalash, A. A. 2011. Biochemical study of oxidative stress markers in the liver, kidney and heart of high fat diet induced obesity in rats. Diabetol Metabol Synd. 3(17):1-8.

Nowacek, J. M. \& Kiernan, J. A. 2010. Education Guide Special Stains and H \& E $2^{\text {nd }}$ Edition. Daco, California.

Pinnick, K. E., Collins, S. C., Londos, C., Gauguier, D., Clark, A., \& Fielding, B. A. (2008). Pancreatic ectopic fat is characterized by adipocyte infiltration and altered lipid composition. Obesity (Silver Spring). 1(6): 522-530.

Rajesh, R., Kotasthane D. S., Manimekalai, K., Singh, A., Sreekala, V., \& Rajasekar, S. S. 2017. Histopathological and Histomorphometric Analysis of Pancreas and Liver of Diabetic Rats Treated with Mucuna pruriens Seed Extract. Annals of
Pathology and Laboratory Medicine. 4(5): A-547-A552.

Sartika, R. T. A. D., Achmad, K., Triyanti, \& Rustika. 2016. Effect of Trans Fatty Acid on Glucose Level and Pancreatic $\beta$ Cell in Rats. Pakistan Journal of Nutrition. 15(8): 760-762.

Suhendro, Susraini, A. A. A. N., Saputra, H. \& Sriwidyani, N. P. 2018. Oral Administration of Neem (Azaradiracta indica Juss) Leaf Extract Increase Cyclin D1 Expression in Hepatocyte Regeneration in Acetaminophen-induced Hepatotoxic Wistar Rats. Bali Med J. 7(1): 12-16.

Supriyanto, Simon, B., Rifa'i, M., \& Yunianta. 2017. Uji Fitokimia dan Aktivitas Antioksidan Ekstrak Daun Mimba (Azaradiracta indica Juss). Prosiding SNATIF ke-4. Fakultas Teknik, Universitas Muria Kudus.

Tandi, J., Rizky, M., Mariani, R., \& Alan, F. 2017. Uji Efek Ekstrak Etanol Daun Sukun (Artocarpus altilis (Parkinson Ex F. A. Zorn) Terhadap Penurunan Kadar Glukosa Darah, Kolesterol Total dan Gambaran Histopatologi Pankreas Tikus Putih Jantan (Rattus norvegicus) HiperkolesterolemiaDiabetes. 1(8): 384-396.

Tjahjono, K., Santoso, \& Ngestiningsih, D. 2013. Trans fatty acids increase nitric oxide levels and pancreatic beta-cell necrosis in rats. Univ Med. 32(1):51-59.

Tuminah, S. 2009. Efek Asam Lemak Jenuh dan Asam Lemak Tak Jenuh "Trans" terhadap Kesehatan. Media Peneliti dan Pengembang Kesehatan. 1(19): S13-S20.

Verlaan, M., Roelofs, H. M. J., Van Schaik, A., Wanten, G. J. A., Jansen, J. B. M. J., Peters, W. H. M., \& Drenth, J. P. H. 2006. Assessment of oxidative stress in chronic pancreatitis patients. World J Gastroenterol. 12(35):5705-5710. 